\title{
BRIDGING THE IMPLEMENTATION OF THE NAGOYA-KUALA LUMPUR SUPPLEMENTARY PROTOCOL ON LIABILITY AND REDRESS IN INDONESIA
}

\author{
Wahyu Yun Santoso* \\ * Faculty of Law, Universitas Gadjah Mada, Yogyakarta, Indonesia

\section{Article Info} \\ Received : 08 November 2015 | Received in revised form : 01 March 2016 | Accepted : 26 April 2016 \\ Corresponding author's e-mail : wahyu.yuns@ugm.ac.id
}

\begin{abstract}
Aside the Nagoya Protocol on Access and Benefit Sharing, which was ratified by the Indonesian government with Law No. 11 Year 2013, the Nagoya-Kuala Lumpur Supplementary Protocol on Liability and Redress (NKL Supplementary Protocol) offers great benefits for a "mega biodiversity" country like Indonesia. Despite the lack of awareness of this supplementary protocol, there is an urgent need for its ratification. This legal-normative research aims to look at the existing regulations in Indonesia to support the implementation of the Nagoya-Kuala Lumpur Supplementary Protocol on Liability and Redress, and to explore the readiness of the national legal system on liability and redress for damages resulting from the application of Living Modified Organisms (LMOS). Based on the several existing regulations, Indonesia has the readiness to a certain extent to implement the Nagoya-Kuala Lumpur Supplementary Protocol on Liability and Redress. This finding should be supported with more intensive discussion on the protocol and its implementationl.
\end{abstract}

Keywords: biodiversity, biosafety, liability, redress

\begin{abstract}
Abstrak
Melalui Undang-Undang Nomor 11 Tahun 2013, Pemerintah Indonesia telah meratifikasi The Nagoya Protocol on Access to Genetic Resources and the Fair and Equitable Sharing of Benefits Arising from their Utilization to the Convention on Biological Diversity. Selain itu, pada momen yang sama Negara Pihak CBD juga menyepakati the Nagoya-Kuala Lumpur Supplementary Protocol on Liability and Redress (NKL Supplementary Protocol) yang menawarkan "kesempatan" besar bagi negara megabiodiversity seperti Indonesia. Penelitian mormatif yuridis ini bertujuan untuk memaparkan kerangka pengaturan yang sudah ada untuk memungkinkan implementasi NKL Supplementary Protocol ini. Berdasarkan beberapa regulasi yang sudah ada, Indonesia memiliki kesiapan dan sekaligus perlu untuk menerapkan protokol terkait pertanggungjawaban hukum dan kompensasi kerugian yang timbul akibat aplikasi Living Modified Organisms (LMOs).
\end{abstract}

Keywords: biodiversitas, transgenik, bioteknologi, kompensasi 


\section{Introduction}

It was the International Year of Biodiversity in 2010. The theme chosen by the United Nations at the time was "Biodiversity is Life, Biodiversity is Our Life". Eventually, it has harvested several essential legal instruments to support the protection and preservation of biodiversity. By the end of the Conference of the Parties (COP) 10 of the Convention on Biodiversity (CBD) in Nagoya, Japan, October that year, the Nagoya Protocol on Access and Benefit Sharing (Protocol ABS) was signed. ${ }^{1}$ This popular protocol entered into force on 12 October 2014. Indonesia as a mega biodiversity country has already ratified the Nagoya Protocol with Law Number 11 Year 2013.

However, another additional result that came out of the Nagoya meeting at the time, namely the Nagoya - Kuala Lumpur Supplementary Protocol on Liability and Redress (NKL Supplementary Protocol), which was agreed upon at MOP5 $2010{ }^{2}$ While Protocol ABS is a direct additional protocol to the Convention on Biological Diversity, the NKL-Supplementary Protocol is an additional protocol to The Cartagena Protocol which was adopted in 2000 and entered into force in 2003. It was a final achievement, since in the process of the adoption of the Cartagena Protocol the issue of "liability and redress" was the only remaining issue. This issue however, had been postponed due to conflict of interest between mainly genetically modified crop exporting countries and importing countries over the relative weights of liability and redress. The first party, who expressed the interest of advanced industrial countries, wish to avoid liability, and in contrast the later parties are those who demanding strict liability are developing countries.

The issue of liability and redress with regard to transboundary damage to biological diversity has been a classic debate. It was one of the topics of discussion during the negotiation of the Convention on Biological Diversity. Unfortunately, at the end, the negotiators were unable to reach a consensus regarding the details of a liability regime under the Convention and consequently postponed the consideration of the issue to a future date. It was stated in paragraph 2 of Article 14 of the CBD which provides that:

"The Conference of the Parties shall examine, on the basis of studies to be carried out, the issue of liability and redress, including restoration and compensation, for damage to biological diversity, except where such liability is a purely internal matter."

It is a relieving achievement that the liability and redress system has been agreed upon after prolonged discussions and meetings. Substantially, the agreement produced was not a guideline, but has been finalized as a legally binding "supplementary protocol". Although it needs to be noted that the legally binding nature of the supplementary protocol has been greatly reduced by the fact that it is dependent on the administrative measures of each respective country. The NKL Supplementary Protocol provides that response measures to address damage can be determined

${ }^{1}$ The Nagoya Protocol on Access to Genetic Resources and the Fair and Equitable Sharing of Benefits Arising from their Utilization to the Convention on Biological Diversity is an international agreement which aims at sharing the benefits arising from the utilization of genetic resources in a fair and equitable way. It entered into force on 12 October 2014. The full text can be downloaded from https://www.cbd.int/abs/ text/default.shtml.

${ }^{2}$ The full title of the protocol is The Nagoya - Kuala Lumpur Supplementary Protocol on Liability and Redress to the Cartagena Protocol on Biosafety. In its decision BS-V/11 the COP-MOP adopted the Nagoya Kuala Lumpur Supplementary Protocol on Liability and Redress in 2010. The NKL Supplementary Protocol provides for international rules and procedure on liability and redress for damage to biodiversity resulting from LMOs. The full text can be downloaded from https: //bch.cbd.int/protocol/NKL_text.shtml. 
by each country under their domestic law, and it is up to each individual country to decide how to apply civil liability rules and procedures.

Nevertheless, as a legally binding supplementary protocol, it is indeed a solid achievement in the context of environmental law development. The scope of international environmental treaty law has greatly expanded since the Stockholm "awakening" regime. This process has, however, not been accompanied by significant developments in the legal rules governing international liability and redress for environmental damage. The appeal to States in both the 1972 Stockholm Declaration and the 1992 Rio Declaration to cooperate to develop further international law regarding liability and compensation for environmental damage has received only limited response to date. It needs to be noted that the legal consequences of environmental harm cover both liability for harm resulting from activities not prohibited by international law as well as state responsibility for violation of international law. The CBD regimes have brought new hope in regulating the trending technology development, namely biotechnology, since it promulgates the safety protocol of transboundary movements of living modified organisms. The issue of liability and redress for damage resulting from transboundary movements of living modified organisms was also one of the critical issues at the time.

Indonesia, which has inherited abundant genetic resources, as a party to the CBD has the responsibility to perform its commitment to protect, preserve, and sustainably manage its biological diversity. Yet, the issue of liability and redress mandated by the NKL-Supplementary Protocol has not been considered as main agenda by the government. This article attempts to explore the existing regulations in Indonesia related to the issue of liability and redress of transboundary movement of living modified organisms. It has become an urgent issue to respond to the ongoing development of transgenic crops in Indonesia. ${ }^{3}$ Yet, the Indonesian Government appears not to be well aware of the NKL Supplementary Protocol. Discussion on existing regulations can be used to describe the readiness of Indonesia and its national legal system to support the implementation of the NKL Supplementary Protocol on Liability and Redress.

After a brief overview of the NKL Supplementary Protocol, this article discusses the available liability and redress mechanism provided for in the Indonesian legal system, particularly under civil law as well as regulations on the environment, food, health, consumer protection, hazardous substances, and plantations. The following discussion is outlined with the existing rules of liability; mechanism to claim and compensate in environmental matters; responsible parties related to biosafety; and existing legal exemptions.

\section{Existing Rules of Liability}

The negotiation and the adoption of the Supplementary Protocol on Liability and Redress were conducted within the legal framework of the Convention on Biological Diversity (CBD) and the Cartagena Protocol. As stated in its objectives:

“...to contribute to the conservation and sustainable use of biological diversity...by providing international rules and procedures in the field of liability and redress re-

${ }^{3}$ Recent progress in transgenic crops development is that, in the middle of 2016, the first official commercial growing of modified maize will be initiated by the Indonesia National Biosafety Commission (KKH). 


\section{lating to living modified organisms",}

The NKL Supplementary Protocol mandates the obligation to establish domestic legal system to address biodiversity damage by requiring operators to take response measures. $^{5}$

The liability regime mandated by the NKL Supplementary Protocol is specific to living modified organisms (LMOs) including genetically modified organisms (GMOs). But because there are fundamentally different perceptions towards LMOs, the NKL Supplementary Protocol keeps a fair distance by stating that the particularities of LMOs being the cause of biodiversity damage have become less of the issue in establishing the liability regime. ${ }^{6}$

"Damage" in the NKL Supplementary Protocol is defined as an adverse effect on the conservation and sustainable use of biological diversity, also taking into account risks to human health, that: (i) is "measurable" and (ii) "significance". " The role of "damage" is defined in administrative approach to liability. Thus, damage is functioning as "a trigger" for administrative actions as well as that the definition of damage as "limits" to administrative discretion. ${ }^{8}$ Furthermore, the NKL Supplementary Protocol states that the operator's liability is incurred in relation to the administrative organ of the government, rather than in relation to the victim of damage. Based on this concept set out by the NKL Supplementary Protocol, discussion on the existing rules of liability is focused on those under the civil code and environmental law.

\section{A. Under Civil Law}

In the concept of common liability under civil law, it is stated that any activities causing damage or loss to another person, inflicts legal liability. The basic rule is set out in Article 1365 of the Indonesian Civil Code (CC). ${ }^{9}$ The article provides that any tort causing damage and loss to another party requires the person causing such damage by its fault to pay compensation. The subsequent Article 1366 CC states that responsibility does not only arise from the damage or loss caused by fault, but also from damage or loss arising from negligence and the lack of caution.

Article 1365 CC provides not only for liability arising from committing an intended culpa (active=culpa in commitendo) but also by not implementing an obligation (passive $=$ culpa in ommitendo),$^{10}$ while Article 1366 CC puts more emphasis on liability from negligence (onrechtmatigenalaten).$^{11}$ It is clear that the key point of liability is the proof of the fault. Accordingly, there are two possibilities: 1) the injured person is also partaking in the fault, which means that he or she bears the same liability as the plaintiff, unless it is a deliberate fault; 2) damage or loss is caused by more than

\footnotetext{
${ }^{4}$ Secretariat of the Convention on Biological Diversity, United Nations Environment Programme, Nagoya-Kuala Lumpur Supplementary Protocol on Liability and Redress to the Cartagena Protocol on Biosafety (2011), art. 1.

${ }^{5}$ Secretariat of the Convention on Biological Diversity, arts. 5 and 12 (1).

${ }^{6}$ Akiho Shibata, "Introduction" in International Liability Regime for Biodiversity Damage: The NagoyaKuala Lumpur Supplementary Protocol, edited by Akiho Shibata, (London: Routledge Publisher, 2014), p. 1-14.

${ }^{7}$ Secretariat of the Convention on Biological Diversity, art. 2 (2)(b).

${ }^{8}$ Shibata, loc.cit.

${ }^{9}$ Basic provisions on unlawful acts in Indonesia arebased on Articles 1365-1367 of the Civil Code (which is also known as BW (Burgeerlijk Wetboek).

${ }^{10}$ Sudikno Mertokusumo, Pengantar Hukum Perdata, [An Introduction to Civil Law] (Yogyakarta: Penerbit Liberty, 1992).

${ }^{11}$ Ibid.
} 
one plaintiff. In such case, all plaintiffs are to bear common liability as a whole. Those principles are firmly upheld in the implementation of civil law under Articles 1365, 1366, and 1367 CC. As is the case with tort liability under the Indonesian Civil Code, anyone can be held liable to compensate as long as both the fault and the causality between fault and damage can be proved. Fault is not only considered as being against the law, but also against public convention and decency.

Furthermore, in proving the fault, there are two basic legal questions which need to be answered: 1) on subjective/abstract meaning: can the person be held liable for the wrong done? And 2) on objective/concrete meaning: is there any force majeure (overmacht) and state of emergency (noodoestand) $?^{12}$ In the second condition someone is liable, however there is no fault as the wrong has been done in a condition of emergency and force majeure. Thus the concept of Article 1365 CC is fully based on tort liability. Liability arises if the fault (schuldelement) in the activity can be proved. Thus, the concept of strict liability is completely different and it cannot be integrated in Article 1365 CC.

There are three basic elements of tort, which are as follows: ${ }^{13}$

a. culpability;

b. concrete injury; and

c. causality between culpability and concrete injury.

In environmental matters, tort liability often causes problems in the proving stages. As in tort litigation, the three main elements must be fulfilled, while the burden of proving causality between breach of duty and the concrete injury is often hard to implement.

In proving the second element, culpability, there are three components which must be fulfilled: ${ }^{14}$

1. deliberately doing the wrong

2. there is a negligence (culpa)

3. there is no excuse clause and exceptional clause for the wrong (rechtvaardigingsgrond).

As for concrete injury or damage (schade), it could consist of material damage (actual injury) and immaterial damage like misery, psychological pain, etc. Thus, the injuction claimed in tort litigation could cover the following: $:^{15}$

a. cash compensation (or fine);

b. restitution;

c. prohibition of repetition; and

d. court decision stating the tort.

The third element of tort is causality. There are two main theorems to define and prove causality:

a. Caution in fact theorem,

This theorem is supported by a well-known jurist from continental Europe, Von Buri, who is the man behind the Condition Sine Qua Non theorem. He

\footnotetext{
${ }^{12}$ H.F Vollmar as cited in Purwahid Patrik, Dasar-Dasar Hukum Perikatan, [ Fundamentals of the Law of Obligations], (Bandung: CV. Mandar Maju, 1994), p. 82.

${ }^{13}$ Mertokusumo, loc.cit.

${ }^{14}$ Ibid.

${ }^{15}$ Ibid.
} 
stated that "everything is a cause of a consequence, while consequence will not occur without a cause". ${ }^{16}$ According to this theorem, anyone who commits tort is always liable as long as it causes damage or loss. Caution in fact is only a matter of fact or something that actually occurred.

b. Adequate causation theorem.

The theorem proposed by Van Kries states that "everything is the cause of a result, if based on the society's experience it can be assumed that the cause will be followed by such result". ${ }^{17}$ According to this theorem, anyone who commits tort is only liable for the damage or loss that can be reasonably expected to arise from such fault. Furthermore, Vollmar states that "causality is shown if the damage or loss is a reasonably expected result from a breach of law or culpa. ${ }^{18}$

\section{B. Under Environmental Law}

Environmental law in Indonesia is considered as lex specialis sistematis. It means that environmental law is designed as a detailed, focused, and special law on regulating matters related to environmental protection and management. The most recent regulation is Law No. 32 Year 2009 on Environment Protection and Management (Environmental Law). Under the Environmental Law regime, liability is categorized into two available mechanisms in court: tort liability under the Civil Code, and strict liability under the environmental law.

Tort liability is applied for more generic activities concerning environmental pollution and damage. Article 87 sets forth the limitation on the application of liability based on fault, while Article 88 limits the application of strict liability. ${ }^{19}$ For liability based on fault, Article 87 (1) states that every operator who has committed fault in terms of environmental pollution and or destruction, and has thus caused damage or loss to someone else, is obliged to pay compensation and/or restoration activities. Hence, it is clear that the concept of Article 1365 CC is applied in the said article.

Meanwhile, Article 88 provides for the concept of strict liability. It is stated that any person whose activities or business use hazardous substances; produce and/ or manage hazardous wastes; and/or inflict serious threats to the environment are strictly liable for the damage resulted without the need to prove the tort. ${ }^{20}$ Although in the Indonesian language the term strict liability is referred to as "tanggung jawab mutlak (absolute liability)", it is clear that the applicable liability is liability under the strict liability regime.

Strict liability can be easily defined as automatic responsibility for damages as strict liability does not take into consideration why the substance was used and does not take ignorance as an excuse. Whether or not the third party intended to cause damage to another's property is irrelevant and the third party will still be held accountable. Damages are usually calculated in accordance with the cost of

\footnotetext{
${ }^{16}$ Rachmat Setiawan, Pokok-Pokok Hukum Perikatan,[Fundamentals of the Law of Obligations], (Bandung: Putra Abardin, 1999). p. 87.

${ }^{17}$ Ibid.

${ }^{18}$ H.F. Vollmar, Pengantar Studi Hukum Perdata [An Introduction to Civil Law Studies], (Jakarta: C.V. Rajawali, 1998), p. 458.

${ }^{19}$ The enactment of strict liability is clearly imposed for any activities having substantially harmful risk to human beings and the environment.

${ }^{20}$ Indonesia (1), Undang-Undang tentang Perlindungan dan Pengelolaan Lingkungan Hidup (Law regarding Environment Protection and Management), UU No. 32 Tahun 2009, LN No. 140 Tahun 2009 (Law Number 32 Year 2009, SG No. 140 Year 2009), Art. 88.
} 
reinstating the property into its initial state before the contaminant was released. Thus the important and priority action is to restore and alleviate the environmental impact, rather than the proving activity. The burden of proof is also shifted to the operator. Indeed, the concept of strict liability is more applicable in civil law cases or related to compensation for damages or losses.

Even though the application of strict liability seems rather simple liability, as it is focused on the activity with significant risk and impact to the environment and human health, there has been a rather low level of its application in Indonesia. As the common liability scheme is liability based on fault, law enforcement agencies (the police, prosecutors, lawyers, and judges) often do not understand the specifics of strict liability and prefer to apply the common one. ${ }^{21}$

Under the Environmental Law regime, there are three mechanisms to impose liability: administrative sanctions, civil actions, and criminal liability. Administrative sanctions can be imposed by the Minister of Environment, Governors, or Regents/ Mayors on parties/operators responsible for business/activities in cases of violation of environmental permits. ${ }^{22}$ Environmental permit itself is an obligation for any business/activities that bring significant and substantial impact on the environment. The types of business/activities are classified and defined under several criteria. ${ }^{23}$

For civil action, to implement both, liability based on fault and strict liability, three types of mechanisms are available: class action, environmental organization legal standing (public litigation), and government legal standing. The last one is a new addition under the Environmental Law. The purpose is of course to grant the right and competence to environmental agencies to act before the law in order to protect the environment and claim compensation for the interest of the environment. The first two mechanisms have been broadly known and accepted by the court system, as they were introduced in 1997 under Law No. 23 Year 1997. ${ }^{24}$

Liability under the Environmental Law, particularly for the introduction of genetically modified products, is more focused on criminal liability. In the previous regulation, Law No. 23 Year 1997, the introduction of genetically modified products is included as a type of environmental pollution. Criminal liability is thus related to the prevention of pollution. Under the new law, pollution is defined as contamination of any creature, substances, energy, and/or other component exceeding the stipulated environmental quality standard. Thus, it is a more "formal" provision, contrary to the previous law, requiring a change in the environmental function in order for it to be categorized as pollution.

\section{Under the Food Law}

There is a well-developed body of regulations concerning liability of genetically modified products under the food law. Law No. 7 Year 1996 regarding Food has created systematic regulation on food, which has been enriched with the new Law No. 18 Year 2012 regarding Food (The New Food Law). Under the New Food Law, the main responsibility for food management is complying with sanitary, food safety,

${ }^{21}$ Based on research initiated by the Indonesian Center for Environmental Law (ICEL) and Van Vollenhoven Institute in 2010 on environmental disputes. It was stated that during 1989-2009 dozens of environmental disputes occurred, however, none of them were resolved with the implementation of the strict liability principle.

${ }^{22}$ Indonesia (1), op.cit., Art. 76.

${ }^{23}$ The list of activities is stated in Minister of Environment Decree No. 5 Year 2012.

${ }^{24}$ The implementation of class action is now provided for under the Supreme Court Regulation No. 1 Year 2002, which has been adopted from the US Federal Rules of Civil Procedure. 
and public safety requirements. Provisions in the New Food Law are based on the preventive principle as well as the precautionary principle. For genetically modified products in any use of production: such as basic ingredients, additional ingredients, or even supplementary ingredients; there is an obligation to undergo the food safety protocol before they are released to the market. ${ }^{25}$

Product liability is imposed under the New Food Law. It is stated that business entities producing processed food are liable for food safety. Subsequently, the liability based on fault adopted in the Civil Code is also implemented within this scope. Thus liability is due to arise when the food produced affects and causes a negative impact on consumers' public health. ${ }^{26}$

However, product liability under the new law is not well maintained. In the previous regulation, the government had the right to represent society in claiming compensation in cases involving an enormous number of victims and an enormous amount of damage/loss. ${ }^{27}$ Furthermore, the flaw that producer could be unknown or located abroad, potentially causing difficulties in imposing liabilities, is prevented by shifting the liability to the distributor or importer of the product. ${ }^{28}$ Unfortunately, under the new regulation, neither of these mechanisms is available.

The New Food Law provides the same provisions as the previous law, under which the basic compliance of business/activities producing or distributing genetically modified product is to conform with the food safety protocol. Failure to follow such procedure is provided for under administrative measures, namely that administrative sanctions are to be imposed for the distribution of genetically modified food without permit and the food safety protocol. ${ }^{29}$ The applicable administrative sanctions include the following: fine, suspension of business activities, retraction of the products concerned, compensation, and/or permit cancellation. However, compensation under the administrative sanction is not adequately spelled out. Thus, the difference between compensation which ought to be sought by civil action is not defined.

Criminal liability is provided for in Article 137 of the New Food Law, setting forth penal sanction for any person who produces genetically modified products, and who uses genetically modified products as main or additional ingredient in their production without government approval of food safety. The applicable sanction is five years of imprisonment and a fine up to Rp10.000.000.000,- (ten billion rupiah). ${ }^{30}$

The delegating provisions for the recent regulation are yet to be issued, thus the previous government regulations are still applicable. The legal basis for food the safety procedure is provided for in Government Regulation No. 28 Year 2004 regarding Safety, Quality, and Nutrition of Food. Another government regulation which is still relevant is Government Regulation No. 69 Year 1999 regarding Food Label and Advertorial. ${ }^{31}$

${ }^{25}$ Indonesia (2), Undang-Undang tentang Pangan (Law regarding Food), UU No. 18 Tahun 2012, LN No. 227 Tahun 2012 (Law Number 18 Year 2012, SG No. 227 Year 2012), Arts. 77 - 79.

${ }^{26}$ Article 79 Law No. 18 Year 2012 states that administrative sanction can be imposed for illegal distribution or production of genetically modified food. The new food law provide for more structured provision with regard to food safety policy, safety protocol, as well as labelling and advertising provisions.

${ }^{27}$ Indonesia (3), Undang-Undang tentang Pangan (Law regarding Food), UU No. 7 Tahun 1996, LN No. 99 Tahun 1996 (Law Number 7 Year 1996, SG No. 99 Year 1996), Art. 43.

${ }^{28}$ Indonesia (3), op.cit., Art. 42.

${ }^{29}$ Indonesia (2), op.cit., Art. 79.

${ }^{30}$ Ibid., art. 137.

${ }^{31}$ Labelling genetically modified products is another remaining issue in Indonesia's legal framework on biotechnology. It is actually mandatory, however in reality, only a few companies implement such responsi- 


\section{Under the Health Law}

The current regulation on health is Law No. 36 Year 2009 (Health Law). Compared to the previous regulation, it addresses issues on biotechnology and genetically modified products in a more comprehensive manner. Under the law, the position of Indonesia in cloning technology for example, is more clear and firm. While in regulating food safety the Health Law provides for product liability on the part of the producer concerned. It is stated in Article 109 that any person and/or legal entity producing, processing, and distributing food and beverages defined as genetically modified products, should ensure the food's safety for human beings, cattle stock, and the environment. ${ }^{32}$

The fulfillment of compliance related to genetically modified products must also be mentioned on the labelling and in promoting genetically modified food or beverages. It is prohibited to use any misleading or deceitful promotion and untruthful claim in producing and promoting technology based food and beverages. Thus, as far as it is concerned, the Health Law is confirming the provisions set forth in the New Food Law, without compromising the extent of the Food Law itself. For example, the provisions on the marketing permit, strengthen (rather than replace) the provisions set forth in the New Food Law. ${ }^{33}$ The Health Law requires producers to comply with the food safety protocol and permits existing under the New Food Law, as well as to comply with the provisions on labelling and packaging. The products' labels and packages should indicate the following information: name of product, ingredient, name of producer or importer, and expiry date.

It needs to be noted that no precautionary approach is adopted in the Health Law. It is quite interesting, as the Health Law also mentions the use of technology. Several components of the precautionary approach, i.e. a precautionary approach is needed in the event that scientific uncertainty arises; there is a need for exploration in order to find alternative measures to settle the problem or damage; and also the need to shift the burden of proof to the producer concerned if a damage occurs. Thus, if a case occurs as a result of intrusion of genetically modified products, not directly related to the Environmental Law, but related to Health Law provisions, the liability scheme likely to be adopted by the court is common liability based on fault.

\section{E. Under the Consumer Protection Law}

Consumer protection is provided for in Law No. 8 Year 1999 (Consumer Protection Law). ${ }^{34}$ Historically speaking, the Consumer Protection Law is among the pioneer and firmly established laws in Indonesia. First, it contains a rather comprehensive protection for customers. Second, it provides for class action procedure as well as environmental law. Third, it creates specific type of liability. And fourth, it states a fair portion of responsibility between customer and producer.

On the protection of product consumption, both customer and producer bear common responsibility. From the customers' perspective, they are obligated to read

bility. It is difficult to find clear examples of products circulating in stores that provide specific labelling as to whether they contain genetically modified products/ingredients.

${ }^{32}$ Indonesia (4), Undang-Undang tentang Kesehatan (Law regarding Health), UU No. 36 Tahun 2009, LN No. 144 Tahun 2009 (Law Number 36 Year 2009, SG No. 144 Year 2009), Art. 109.

${ }^{33}$ Ibid., Art. 110.

${ }^{34}$ In recent developments, consumer protection has been a major issue in Indonesia, as there is currently a specific body to manage this issue, not only by generally known NGOs. At the present time, Indonesia has the Institution for National Consumer Protection (LPKN). 
and follow the information, to read and follow the manual instruction or procedure in using the product for safety and security. ${ }^{35}$ Meanwhile, producers are also obligated to ensure that the quality of the product is based on valid quality standards regulated by the government. ${ }^{36}$ In order to avoid the problem of information assymetry, producers are also obligated to state clear, reasonable, and easy to understand information on the product.

As for product liability, in the event of defective products, the consumer protection law provides that producers are responsible for three types of defect: 1) production/ manufacturing defects, when the product does not meet the requirements; 2) Design defects, when the risk of the product is higher compared to the benefit obtained; and 3) Warning or instruction defects, when information provided on the product is insufficient. Under the customer protection law, product liability can be implemented under three circumstances: 1) breach of quality assurance, 2) negligence, and 3) shifting the burden of proof to the producer.

Liability under the consumer protection law is defined in an interesting way. In general cases, liability based on fault under the Civil Code is to be imposed. Accordingly, anyone who suffers damage or loss due to a product can hold the producer liable. The tort liability mechanism is stated in Article 19 (1) of the Consumer Protection Law. ${ }^{37}$ Moreover, the concept of goods is defined broadly, as both tangible and intangible products are included in the scope of liability. Thus the customer has a wide range of argumentation to demand product liability. Under liability based on fault, liability arises for two reasons: 1) based on fault, where it can be stipulated based on the form of default, breach of law, or less cautious acts; and 2) based on risk of the production activities.

Interestingly, the subsequent articles related to compensation and damages resulting from false advertorial and imported products, Article 22 provides that the responsibility to prove the fault is the burden of the producer concerned, without limiting the duty of the prosecutor to prove the wrong. ${ }^{38}$ This means that the customer protection law imposes both liability based on fault as well as strict liability. In reality the mix between the two types of liability often create problems. The rationale behind the choice made by the lawmaker could be explained in the following three ways: 1) the customer is not in a favorable position to prove fault in a complex production and distribution process; 2 ) it is assumed that the producer is in a better position to handle and anticipate the claim than the customer as plaintiff; and 3) it stipulates precautionary approach by the producer.

\section{F. Under the Hazardous Substances Regulations}

The management of hazardous substances and hazardous materials comes under the environmental law. There are two Government Regulations regarding hazardous substances as delegating provisions of the Environmental Law (Law Number 32 Year 2009). These regulations are related to hazardous substances (Government Regulation No. 74 Year 2001) and hazardous waste management (Government Regulation No. 18 Year 1999 jo. Government Regulation No. 85 Year 1999). Under these two regulations, and strengthened by the Environmental Law, liability is borne by all related parties in

\footnotetext{
${ }^{35}$ Indonesia (5), Undang-Undang tentang Perlindungan Konsumen (Law regarding Consumer Protection Law), UU No. 8 Tahun 1999, LN No. 42 Tahun 1999 (Law Number 8 Year 1999, SG No. 42 Year 1999), Art. 5.

${ }^{36}$ Ibid., Art. 7.

${ }^{37}$ Ibid., Art. 9.

${ }^{38}$ Ibid., Art. 22.
} 
the handling of hazardous materials and producers of hazardous wastes.

Under the Environmental Law, strict liability is imposed for activities using hazardous materials or producing hazardous wastes. Strict liability means that liability is imposed in the absence of fault, knowledge, intent, negligence, breach of contract, or any other direct or indirect wrongdoing by the person held responsible. The liability is strictly related to the permit. In the criminal sanction, it is defined that any activities not processing their hazardous waste, or processing without a permit, is a violation of the law.

\section{G. Under the Plant Law}

Hazardous substances related to genetically modified products include pesticides and the like. Under Indonesian law, regulation related to pesticides is set out in the Law No. 12 Year 1992 regarding Plant Cultivation System (Plantation Law). Under the said law, it is mandated that pesticides which are to be circulated, stored, and used must be registered and permitted by the Minister of Agriculture. Apart from such obligation, pesticides must also meet quality standards, their effectiveness should be guaranteed, they should be safe for human beings and the environment, and they also have to be labelled. ${ }^{39}$

Furthermore, Government Regulation No. 6 Year 1995 regarding Plant Protection sets forth that pesticides as control instruments for Plant Disturber Organisms are used as the ultimate alternative. ${ }^{40}$ Thus, pesticides could be used under two conditions: 1) there is no other alternative instrument which can be used; and 2) the negative impact should be kept to the lowest minimum level. Registered pesticides must comply with administrative and technical criteria regulated by the Minister of Agriculture. Some additional compliance requirements in using pesticides is defined in the following six categories of properness:

a. Proper type of pesticide, for example to control bugs we use insecticides, while when we wish to control fungi of course fungicides are the answer.

b. Proper in the dose, the amount of pesticides used in a field must be calculated precisely and as recommended by the manual or instruction.

c. Proper in the method, there is a specific way for using different pesticides and the right method must be applied.

d. Proper in purpose, the variety of plantations is also a major consideration in using certain pesticides.

e. Proper in time, this is related to the exact time when pesticides must be used in order to get the optimal results.

f. Proper in place, the type of the land is also a substantial consideration in choosing the right pesticides.

As pesticides are considered to be hazardous materials, the liability scheme that can be imposed is the same as the one set forth in the Environmental Law. Under the Environmental Law, strict liability is imposed for activities: 1) having and resulting in substantial impact on the environment; 2) producing, carrying, distributing, utilizing, disposing, and processing hazardous and toxic materials; and 3) producing hazardous and toxic wastes.

\footnotetext{
${ }^{39}$ See Law No. 12 Year 1992 regarding Plant Cultivation System.

${ }^{40}$ See Government Regulation No. 6 Year 1995 regarding Plant Protection.
} 


\section{III.Mechanism to Claim and Compensate in Environmental Matters}

The mechanism to claim and compensate in environmental matters under Law No. 32 Year 2009 on Environment Protection and Management (Environmental Law) can be either by non-litigation settlement or by litigation. By non-litigation, the environmental dispute can seek out-of-court settlement via mediation and arbitration. While by litigation means taking civil action, defined as one of the following three mechanisms: class action, public interest litigation, and citizen lawsuit.

\section{a. Civil Procedure}

Under the civil procedure, claim for compensation can be filed with the court based on tort liability (Articles 1365 - 1367 of the Indonesian Civil Code (CC). Article 1365 $\mathrm{CC}$ states that any breach of law (tort) causing damage/loss to someone else, triggers the liability to compensate for the damage/loss caused. Meanwhile Article 1366 CC states that liability arises not only for fault or culpability, but also for negligence or the lack of caution. Furthermore, Article 1367 CC states that the liability to compensate for any damage/loss is not only for one's deed, but also for the amenability under one's guardianship.

These three articles are used as the legal basis of liability based on fault in Indonesia. The definition and limitation of fault and liability are quite clear under these articles. Compensation can be sought both for material as well as immaterial damages. In general, damages are calculated in currency, although in some instances the claim can also include the replacement of damaged goods. Based on the provisions of Article 1365 CC, it can be interpreted that in a limiting manner, the Indonesian Civil Code adheres to the principle that compensation is mandatory for any damage/ loss caused by tort. In several cases, judges ex-officio have determined an amount of compensation even though the injured party did not ask for any compensation.

Theoretically, the following two types can be used to define damage or loss: actual loss and future loss. Actual loss is based on concrete injury occurring as a result of the fault concerned. At the same time, future loss is a presumption of "to be injured" if the fault caused it. Such compensation can be in the form of vindication in the printed media. Both types of loss must be based on rational and reasonable calculation.

Under Article 1365 CC, there are six types of available compensation which can be sought before the court:

1) Actual cost of damage or loss.

2) Compensation in kind or restitutio in integrum.

3) Statement that the deed is considered as fault or a breach of the law.

4) Restriction to do something.

5) Nullify something illegally held.

6) Public announcement of a sentence or a restitution.

Furthermore, under Article 1246 CC related to default in contractual agreement, redress can also be manifested in three types of compensation: any actual cost must be paid by the injured party; damage or loss caused by tort or default made by the other party; and also interest for any profit can be obtained as if the damage had never occurred. However, the concept of damage/loss due to default is quite different from the damage/loss caused by tort. Thus, the amount of compensation literally depends on the judge's decision. 


\section{b. Out of Court Settlement}

The objective of conducting out of court dispute settlement is to reach an agreement on the following matters: 1) form and amount of compensation, 2) actions to recover consequences of pollution and/or destruction, 3) certain actions to ensure that pollution/destruction will not be repeated, and 4) actions to prevent negative impacts on the environment from occurring. ${ }^{41}$ The limitation is that this settlement is not to be applied to criminal acts related to the environment.

Communities may establish environmental dispute settlement service provider institute, and the government may facilitate one as well. Within the institute, services of mediators and arbiters may be used to help resolve the dispute. There is no limitation on the requirement to become environmental mediator. The only requirements are meeting the basic requirement of minimum 35 years old of age, and having five years of experience in environmental matters. Whilst for arbitration, the required experience is ten years besides having certificate as arbiter.

At the practical level, out of court settlement is more effective if it is mediated by the government (environmental agency). This fact is of course influenced by the bargaining position of the mediator (environmental agency) especially for the execution of the agreement. In several regional governments, the environmental agency frequently provides an ad-hoc committee for settling environmental disputes.

\section{c. Class Action}

Fundamental differences between a class action lawsuit and a civil lawsuit pursuant to the procedure applicable in Indonesia lie in the following: 1) preliminary case examination (prior to the examination of the main case), whereby during the examination of class action, there are the certification and notification stages, and (2) the stage of verdict execution, whereby a class action must involve an examination or tentative settlement proposal and notification to distribute the determined compensation.

Environmental law under Law No. 23 Year 1997 pioneered the mandating of class action mechanism in the law. It was subsequently followed by other regulations such as Law No. 18 Year 1998 regarding Consumer Protection (Consumer Protection Law), and Law No. 41 Year 1999 regarding Forestry. To date, a great number of cases have been brought to claim compensation, whether in environmental damage or otherwise, within the class action mechanism. The guidelines have also been quite clearly articulated with the enactment of Supreme Court Regulation (PERMA) No. 1 Year 2002 regarding the guidelines for filing for class action and public litigation civil procedure. These guidelines have adopted to a certain extent practices in the United States: the Federal Rules of Civil Procedure, particularly Rule 23. Thus it is significant to maintain the four basic components in filing a class action lawsuit: numerousity of the party, typicality of the claim, commonality of the legal facts, and adequacy of representation.

Under the new Environmental Law (Law No. 32 Year 2009), there is a new addition on Anti-SLAPP mechanism. Anti-Strategic Lawsuit Against Public Participation is mentioned in Article $66 .^{42}$ Indeed, it provides a broad golden chance for greater protection of the environment, as anyone who reports or acts as a witness of an environmental crime gets protection and may not be accused of defamation or

\footnotetext{
${ }^{41}$ Indonesia (1), op.cit., Art. 85.

${ }^{42}$ Ibid., Art. 66.
} 
otherwise, or to be sued in civil procedure. Nonetheless, the justice system is not firmly ready for the implementation of such protection.

\section{d. Public Interest Litigation}

Conceptually, there is a fundamental difference between class action and an NGO's standing to sue. First, class actions comprise class representatives and class members, whereby both are the victims or the parties severely affected. While, under the NGO's standing to sue, an NGO plaintiff is not the party severely affected. Secondly, in the environmental context, as the party representing environmental protection, a right to damages in the NGO's standing to sue is not the scope guaranteed by the law. In contrast, in the class action concept in general, it leads to a compensation demand.

After some attempts to bring class procedures, a successful public litigation effort emerged in Indonesia in 1988 when an NGO, Indonesia's Forum for Environment (WALHI)'s Foundation, brought a public interest claim questioning public access to information, the legality of environmental impact analysis conducted by a paper company, and resulting pollution and environmental degradation. The court shifted its conventional legal standing doctrine (formerly point d'interest, point d'action) by permitting an environmental organization to file a lawsuit in the name of public interest.

Under the Environmental Law regime, the legal standing for NGOs claims can be used for seeking a compensation but limited to restitution of the environment only. The requisites for NGOs are as follows:

1) a legal entity proven by Ministry of Justice Decree;

2) the main activities/purpose of the organization is in environmental matter as indicated in the statute; and

3) active implementation of the purpose with a minimum of two years of actual activities in environmental matters.

There is a new introduction of governmental legal standing, or public interest litigation conducted by the environmental agency. The mechanism and rules are same as the common public interest litigation. The only difference is that it is brought by the government and particularly from the agency that competence of which includes environmental matters.

\section{e. Citizen Lawsuit (actio popularis)}

A citizen suit or actio popularis is a lawsuit by a private citizen to enforce a statute. It is prevalent in common law countries, but not in Indonesia. The initiative of citizen lawsuit started in 2002, when Munir, et. al from Migrant Care Indonesia filed an actio popularis lawsuit before Pengadilan Negeri Jakarta Pusat (Central Jakarta District Court) suing the President for negligence in acting effectively thus neglecting the migrant workers in Nunukan who were deported from Malaysia. The judge accepted and approved the claim. The result of this effort is Law Number 39 Year 2004 regarding the Placement and Protection of Indonesian Migrant Workers. ${ }^{43}$

Following are some specific elements of actio popularis lawsuit: 1) the petitum of

${ }^{43}$ Ana Shabana Azmy, "Negara dan Buruh Migran Perempuan: Kebijakan Perlindungan Buruh Migran Perempuan Indonesia Masa Pemerintahan Susilo Bambang Yudhoyono 2004-2010 (Studi Terhadap Perlindungan Buruh Migran Perempuan Indonesia Di Malaysia)," [The State and Women Migrant Workers: Policy for the Protection of Indonesian Women Migrant Workers During the Governance of Susilo Bambang Yudhoyono 2004-2010 (A Study of the Protection of Indonesian Women Migrant Workers in Malaysia)]. (Thesis Faculty of Social Science and Politic Universitas Indonesia, Jakarta 2011). 
the claim must contain a request ordering the State (government) to issue a public policy or regulation (regeling) in order to stop and prevent any redundancy of the alleged negligence; 2) the petitum cannot contain any dismissal of administrative decree which is concrete, individual, and final; 3 ) the petitum cannot contain either a dismissal of law and under the hierarchy. ${ }^{44}$

\section{Responsible Parties on Biosafety}

\section{A. Law Regarding Individuals}

Indonesian Civil Law divides the liability related to the responsible parties into two types:

a. Direct responsibility regulated under Article 1365 of the Indonesian Civil Code (CC). Since the interpretation of tort in the broad meaning after the Arrest (decision) of the Hooge Raad on 31 January 1919 in the case of Lindenbaun $\mathrm{v}$. Cohen, the concept of tort has also developed under the Indonesian Civil Code, and matters previously not actionable or sanctioned were altered. ${ }^{45}$ The decision stated that the definition of tort or culpability should be limited to a breach of the existing law (onwetmatig), but also the breach of other peoples' right, being against the legal obedience, or against morality.

b. Indirect responsibility regulated under Article $1367 \mathrm{CC}$ implies that a legal person can also bear the responsibility of another person under his responsibility, or in case of goods that under his control. Accordingly, there are several subjects for indirect responsibility:

1) parents or guardians responsible for their underage children;

2) curator responsible for the curandus;

3) teachers responsible for the students in the school neighborhood;

4) employers responsible for employees; and

5) commanders responsible for their subordinates.

The concept of individual or legal person under the Civil Code is the basic definition interpreted in the recent law. In the environmental law, health law, food law, and several other laws related to biosafety, any provision mentioning "anybody" ("barang siapa") is defined as "individual or business entity whether or not incorporated in the form of statutory body (legal entity)".

${ }^{44}$ To date, several actio popularis claims have been brought before the court. For example: actio popularis lawsuit by LBH Apik against Bappenas, the President of Indonesia, and DPR RI (House of Representatives of the Republic of Indonesia) for the increase of gasoline price in 2006, however, it was rejected by the court; actio popularis lawsuit by LBH Jakarta against the Provincial Government of Jakarta for the Yustisi Operation (screening non-local residents) in 2007, which was rejected by the government; and finally, the actio popularis lawsuit by LBH Jakarta and Education Forum against the Minister of Education for the Failure and Mess in the National Exam management in 2010. In the Supreme Court decision, it was partially granted and ordered the government to revise and redesign the national policy on National Exam management. Case Register No. 2596 K/PDT/2008 on the citizen lawsuit from Kristiono, et.al against the President of the Republic of Indonesia, the Ministry of Education, and the Head of National Education Standardization Body.

${ }^{45}$ It is interesting, as well as ironic, that the Indonesian Civil Code is still based on the Netherlands Burgerlijk Wetboek (BW) 1912. The basic and first two books, among 4 books of BW, is still used and applied. Even in the Netherlands itself, the product has already retracted and replaced with new concepts of civil code. 


\section{B. Law Regarding Corporation}

Law No. 40 Year 2007 regarding Limited Liability Company is the basic regulation on corporations in Indonesia. Under this law, particularly Article 74, corporate social and environmental responsibility is defined as legal compliance which must be implemented by a company. The responsibility is applied for any company conducting activities in the natural resources management or related to the environment and natural resources. Accordingly, the responsibility for community life and the environment is not only applicable to companies whose main activities are natural resources management, but also to any company whose activities bring a significant impact on the environment and the life of the community.

Under the Food Law, Consumer Protection Law, and Health Law, it is clear that corporate liability is related to product liability, civil liability in the event of damage occurring, and criminal liability. Under the consumer protection law, product liability is applied as strict liability, whereby liability lies with the producer as long as there is no intentional change made by the reseller or another business entity. Whilst under the environmental law, corporate liability is also imposed in the permit procedure and the obligation for environmental audit, in addition to the basic liability including product liability, civil liability, strict liability, and corporate criminal liability.

Corporate criminal liability is liability imposed upon a corporation for a criminal act committed by a natural person. Liability is imposed so as to regulate the acts of a corporation. The principle of corporate criminal liability is based on the doctrine of respondent superior which is commonly known as the theory of vicarious liability, where the employer/head of a company is made liable for the acts of his employees/ subordinates. Any corporation can be made liable for acts of its workers if he/she: 1) commits a crime; 2) acts within the scope of employment; and 3) with the intent to benefit the corporation. Based on the concept of corporate criminal liability, criminal offense and penalty is imposed on: a) the business entity concerned, and b) the person giving order to commit the crime or the person acting as the executive of the activity in the criminal act concerned.

The currently developing and ongoing topic related to corporate liability is corporate citizenship. Under this concept, the corporation is recognized as a citizen, with its specific rights and duties. Concurrently, this idea is being developed towards the inclusion of corporate duties in Indonesian law. In recent regulation, "anybody" ("barang siapa") is defined as "individual or business entity whether or not incorporated in the form of statutory body (legal entity)", which expands the legal position of a corporation, as well as its liability.

\section{Law Regarding Governmental Acts and Public Researchers}

The liability of government officials as ethical authorities is specifically set out in Law No. 35 Year 2009 regarding Public Services (Public Services Law) and Environmental Law (Law No. 32 Year 2009). The Public Services Law provides for the duty of public servants in providing prime services to the public. However, it only provides for abstract liability rules related to a lack of public services, without any provision stating liability for compensation.

Specific sanctions for public officials are set out in Law 32/2009. Under the administrative procedure, the time limit for the AMDAL (environmental impact study) process, for example, has significant consequences if it is exceeded. In the preliminary process of AMDAL, the assessment process for the proposal is set within 
30 workdays. If the time limit is exceeded, the applicant can assume that the proposal has been approved, and no one can object to such decision. Thus, technically speaking, it can indeed be interpreted as liability for government officials to process the permit application in a timely manner.

Furthermore, the liability of government officials, also related to permits, is criminal liability. In Article 111 it is stated that public officials granting environmental permit without AMDAL or UKL-UPL are subject to the maximum imprisonment for three years and the maximum fine of 3 billion rupiah. In the subsequent article, the negligence of authorized officials in supervising compliance of a business activity, which causes environmental pollution and/or damage that costs human life shall be subject to imprisonment for one year and a fine of 500 million rupiah at the maximum. ${ }^{46}$ Such liabilities imposed on public officials are a good shortcut to ensure prime services in environmental protection.

While for public researchers, the applicable law is Law No. 18 Year 2002 regarding the National System of Research, Development, and Application of Science. The main liability concerned is for any research, development, and application of science which contains a high level of risk and causes potential harm to human beings and the environment. For such activities, permit is a mandatory requirement, and relevant regulations are also applied for criminal liability.

\section{Legal Exemptions}

\section{A. Affirmative Defenses}

Affirmative defense is related to the objectivity of a tort. With this defense, liability can be altered when the component of culpability cannot be fulfilled. Affirmative defense is categorized into two types: justification and excuses. Under Indonesian law, justification consists of the following: 1) overmacht, 2) righteous and forced selfdefense (noodweer), 3) constituting a law, and 4) for implementing a legitimate duty.

Under civil law, particularly in Articles 1244 and 1245 of the Indonesian Civil Code (CC), the liability for making a compensation can be revoked as long as it is due to "unforeseen circumstances" that cannot be anticipated and the defendant can prove such conditions. It is further stated in Article 1245 CC that the liability can also be revoked in the event of a force majeure. The implementation is limitative under the CC.

Based on Indonesian law, affirmative defense is allowed in several conditions:

- Unforeseen circumstance occurring without any available measures to overcome such circumstance.

- Force majeure that compels debtors to undertake certain acts, or to breach the law.

- An accident or unintended incident.

Whereas legal excuses are more closely related to the subjectivity of the fault concerned. Under the criminal law, excuses include conditions faced by a person in a certain condition (threatening his/her life) compelling him/her to act in a certain way which can be considered as a crime. According to this definition, excuses affect the element of a crime or element of a tort/culpability. Under criminal law, excuses are defined as follows:

\footnotetext{
${ }^{46}$ Indonesia (1), op.cit., Art. 112.
} 
1) the subject concerned lacks competence to bear liability;

2) self-defense beyond reasonable limit; and

3) good faith in executing unlawful command post.

Under civil law, similarly to criminal law, excuses can be applied under the following three conditions:

1) unexpected conditions or unforeseen circumstances prior to entering into contract, and it is not possible to counter the condition occurring after the contract has been entered into Accordingly, such condition is beyond the debtor's liability.

2) There is no bad faith behind the default. It means that the response of each party, particularly of the debtor, is a normal response, without any excess.

The excuses eliminate the liability for compensation, even though the Civil Code does not offer any further explanation on the definition. The only article which defines the limitation is Article 1367 CC stating that the liability to compensate is over once the subjected party is able to prove that the act or condition occurred beyond their responsibility.

\section{B. Statute of Limitation}

The statute of limitation is a reason and condition to be freed from a liability after exceeding a certain time frame and fulfilling the criteria set out in the law. The act of revoking liability can be stated anonymously or definitively. The application is common as applied in other legal systems. For example, in the application of the statute of limitation in property ownership, it presupposes a claim, and proof to show the effective occupation of such claim. However, it is limited to rightful owners. It cannot be applied to a tenant, keeper, or anyone else "in possession of" a property under the control of its owner.

The statute of limitation for any claim, property or personal fault, is fulfilled after thirty years. Indeed, apart from this general provision, it is also specifically set out in certain laws. Claim of compensation for any loss in medical treatment, for example, expires after two years. This provision is also applied in legal services. For trade activities and construction work, the statute of limitation is five years. While for customer protection, for any goods, the statute of limitation is four years or as specifically agreed otherwise.

For environmental cases, however, there are two different statutes of limitation. For cases that are common or environmental standard based pollution cases, the expired date applicable is as regulated by the civil code. However, in a business or activity using and managing hazardous materials, as well as business or activity producing and managing hazardous wastes, there is no statute of limitation.

\section{VI.Conclusion}

In view of the main objective of this article, namely to provide a brief description of the existing liability and redress regulations in Indonesia, the following conclusions can be drawn from the foregoing elaboration. Based on actual conditions and existing laws in Indonesia, the main question that needs to be addressed in the context of the implementation of the NKL-Supplementary Protocol in Indonesia is related to the extent and political will of the government to implement the liability and redress mechanism within the context of biosafety. 
The NKL-Supplementary Protocol is a legally binding instrument, thus it fully depends on the national liability mechanism to address the issue of the impacts of genetically modified products. The existing liability mechanism focuses on the remediation of concrete, measurable and quantifiable (in monetary terms) damage that has already occurred. Yet, practical examples indicate that immaterial damages are often difficult to calculate and claim. Meanwhile, when we are concerned about genetically modified products, we deal with unprecedented risk and impacts. There is a question of scientific uncertainty in every impact potentially occurring from the use and application of genetically modified products. On the other hand, the national liability provision should ensure that there will be no legal uncertainty which would discourage the development and use of genetically modified products. Thus, a comprehensive study on the existing liability and redress mechanism, and a "summary framework" which can be used as basic guidelines is definitely a mandatory task for the government.

\section{Bibliography}

\section{Legal Documents}

Indonesia. Kitab Undang-Undang Hukum Perdata (Indonesian Civil Code). Indonesia. Ministry of Agriculture. Keputusan Menteri Pertanian tentang Ketentuan Keamanan Hayati Produk Bioteknologi Pertanian Hasil Rekayasa Genetik (Decree of Minister of Agriculture regarding Conditions on the Biosafety of Genetically Modified Agricultural Biotechnology Products). No. 56/Kpts/ HK.330/9/1997.

Indonesia. Peraturan Pemerintah tentang Keamanan Hayati Produk Rekayasa Genetik (Government Regulation regarding Biosafety of Genetically Modified Products). PP No. 21 Tahun 2005, LN No. 44 Tahun 2005 (Law No. 21 Year 2005, SG No. 44 Year 2005).

Indonesia. Ministry of Agriculture. Keputusan Menteri Pertanian tentang Pembentukan Tim Pengendalian Kapas Transgenik(Decree of Minister of Agriculture regarding Establishment of Transgenic Cotton Control Team). No. 305/Kpts/ Kp.150/5/2001.

Indonesia. Peraturan Pemerintah tentang Keamanan, Mutu dan Gizi Pangan (Government Regulation regarding Food Safety, Quality, and Nutrition). PP No. 28 Tahun 2004, LN No. 107 Tahun 2004 (Government Regulation No. 28 Year 2004, SG No. 107 Year 2004).

Indonesia. Peraturan Pemerintah tentang Pengelolaan Limbah Bahan Berbahaya dan Beracun (Government Regulation regarding Hazardous Waste Management). PP No. 101 Tahun 2014, LN No. 333 Tahun 2014 (Law No. 101 Year 2014, SG No. 333 Year 2014).

Indonesia. Peraturan Pemerintah tentang Perlindungan Tanaman (Government Regulation regarding Plant Protection). PP No. 6 Tahun 1995, LN No. 12 Tahun 1995 (Government Regulation No. 6 Year 1995, SG No. 12 Year 1995).

Indonesia. Peraturan Presiden tentang Komisi Keamanan Hayati Produk Rekayasa Genetik (Presidential Regulation regarding Biosafety Commission on Genetically Modified Products). Perpres No. 39 Tahun 2010 (Presidential Decree No. 39 Year 2010).

Indonesia. Undang-Undang tentang Kesehatan (Law regarding Health). UU No. 36 Tahun 2009, LN No. 144 Tahun 2009 (Law Number 36 Year 2009, SG No. 144 Year 2009). 
Indonesia. Undang-Undang tentang Pangan (Law regarding Food). UU No. 7 Tahun 1996, LN No. 99 Tahun 1996 (Law No. 7 Year 1996, SG No. 99 Year 1996).

Indonesia. Undang-Undang tentang Pangan (Law regarding Food). UU No. 18 Tahun 2012, LN No. 227 Tahun 2012 (Law No. 18 Year 2012, SG No. 227 Year 2012).

Indonesia. Undang-Undang tentang Pengesahan Protokol Cartagena tentang Keamanan Hayati atas Konvensi tentang Keanekaragaman Hayati. (Law regarding the Ratification of Cartagena Protocol). UU No. 21 Tahun 2004, LN No. 88 Tahun 2004 (Law No. 21 Year 2004, SG No. 88 Year 2004).

Indonesia. Undang-Undang tentang Pengesahan Protokol Nagoya tentang Akses Pada Sumber Daya Genetik Dan Pembagian Keuntungan Yang Adil Dan Seimbang Yang Timbul Dari Pemanfaatannya Atas Konvensi Keanekaragaman Hayati (Law regarding the Ratification of Nagoya Protocol on Access to Genetic Resources and the Fair and equitable Sharing of Benefits Arising from their Utilization to the Convention on Biological Diversity). UU No. 11 Tahun 2013, LN No. 73 Tahun 2013 (Law No. 11 Year 2013, SG No. 73 Year 2013).

Indonesia.Undang-Undang tentang Pelayanan Publik (Law regarding Public Services). UU No. 35 Tahun 2009, LN No. 143 Tahun 2009 (Law No. 35 Year 2009, SG No. 143 Year 2009).

Indonesia. Undang-Undang tentang Pengesahan United Nations Convention on Biological Diversity (Konvensi Perserikatan Bangsa-bangsa Mengenai Keanekaragaman Hayati) (Law regarding the Ratification of United Nations Convention on Biological Diversity). UU No. 5 Tahun 1994, LN No. 41 Tahun 1994 (Law No. 5 Year 1994, SG No. 41 Year 1994).

Indonesia. Undang-Undang tentang Perlindungan dan Pengelolaan Lingkungan Hidup (Law regarding Environment Protection and Management). UU No. 32 Tahun 2009, LN No. 140 Tahun 2009 (Law Number 32 Year 2009, SG No. 140 Year 2009).

Indonesia. Undang-Undang tentang Perlindungan Konsumen (Law regarding Consumer Protection Law). UU No. 8 Tahun 1999, LN No. 42 Tahun 1999 (Law Number 8 Year 1999, SG No. 42 Year 1999).

Indonesia. Undang-Undang tentang Perseroan Terbatas (Law regarding Limited Liability Company). UU No. 40 Tahun 2007, LN No. 106 Tahun 2007 (Law No. 40 Year 2007, SG No. 106 Year 2007).

Indonesia. Undang-Undang tentang Sistem Budidaya Tanaman (Law regarding Plant Cultivation System Law). UU No. 12 Tahun 1992, LN No. 46 Tahun 1992 (Law No. 12 Year 1992, SG No. 46 Year 1992).

Indonesia. Undang-Undang tentang Sistem Nasional Penelitian, Pengembangan, dan Penerapan Ilmu Pengetahuan (Law regarding National System of Research, Development, and Application of Science Law). UU No. 18 Tahun 2002, LN No. 84 Tahun 2002 (Law No. 18 Year 2002, SG No. 84 Year 2002).

\section{Books}

Bahagiawati and M. Herman. Isu dan Fakta tentang Tanaman Produk Bioteknologi. [Issues and Facts concerning Biotechnology Product Plants]. Bogor: Balai Besar Penelitian Bioteknologi dan Sumber Daya Genetik Pertanian, 2008.

CropLife International. Compliance Management of Confined Field Trials of Genetically Engineered Plants. Brussels: CropLife International, 2005.

CropLife International. A Guideline For Liability And Redress Mechanism Under NKLSupplementary Protocol. Brussels: CropLife International, 2010.

Purwantara, Bambang. and M. Thohari. Eds. Status Global Tanaman Produk Rekayasa Genetik dan Regulasinya [Global Status of Genetically Modified Plants and 
Related Regulation]. Bogor: Balai Besar Penelitian dan Pengembangan Bioteknologi dan Sumber Daya Genetik Pertanian, 2012.

Secretariat of the Convention on Biological Diversity. Nagoya - Kuala Lumpur Supplementary Protocol On Liability And Redress To The Cartagena Protocol On Biosafety. New York: United Nations. 2011.

Shibata, Akiho. Ed. International Liability Regime for Biodiversity Damage: The Nagoya-Kuala Lumpur Supplementary Protocol. London: Routledge Publisher. 2014.

\section{Articles}

Bahagiawati and M. Herman. "Perkembangan Bioteknologi Dan Status Regulasi Di Indonesia." (Paper for Workshop on The Use of Biotechnology in Overcoming Food Crisis, Jakarta, 28 August 2008).

Bahagiawati and M. Herman. "Regulasi, Implementasi Dan Kendalanya Dalam Pemanfaatan Produk Bioteknologi Di Indonesia." (Paper for Workshop "Will Biotechnology Impact Food Security?" held by PBS, MSU, IndoBIC, CropLife, and BB-Biogen, Jakarta, 14 October 2008).

Elliot, Kevin C. and Michael Dickson. "Distinguishing Risk and Uncertainty in Risk Assessments of Emerging Technologies." Pantaneto Issue 48 (October 2012).

Herman, M. "Tanaman Hasil Rekayasa Genetik Dan Pengaturan Keamanannya Di Indonesia. [Genetically Modified Plant and its Safety Regulations in Indonesia]" Buletin AgroBio 3 (1) (1999): 8-26.

James, Clive. "Global Status of Transgenic Crops in 1997." (ISAAA Brief No. 5. Ithaca, New York, 1997).

James, Clive. "Global Review of Commercialized Biotech/GM Crops: 2009." (ISAAA Brief No. 41, Ithaca, New York, 2009).

James, Clive. "Global Review of Commercialized Biotech/GM Crops: 2014." (ISAAA Brief No. 56, Ithaca, New York, 2014).

Kameri-Mbote, Patricia. "Towards A Liability And Redress System Under The Cartagena Protocol On Biosafety: A Review Of The Kenya National Legal System." East African Law Journal 1 (2004): 25-37.

Kiplagat, Betty. "Liability \& Redress: The Supplementary Protocol To The Cartagena Protocol On Biosafety." (NEPAD: Legal/Policy Aspects ABNE Policy Brief No. 2. 2013).

Myhr, Anne Ingeborg. "A Precautionary Approach to Genetically Modified Organisms: Challenges and Implications for Policy and Science." Journal of Agriculture and Environment Ethics 23 (2010):501-525. 